GRASAS Y ACEITES 65 (1)

January-March 2014, e004

eISSN-L: 0017-3495

doi: http://dx.doi.org/10.3989/gya.051513

\title{
Antioxidant capacity of the phenolic fraction and its effect on the oxidative stability of olive oil varieties grown in the southwest of Spain
}

\author{
M.N. Franco ${ }^{\mathrm{a}}$, T. Galeano-Díaz ${ }^{\mathrm{b}}$, J. Sánchez $^{\mathrm{a} \bowtie}$, C. De Miguel ${ }^{\mathrm{c}}$, and D. Martín-Vertedor ${ }^{\mathrm{a}}$ \\ aTechnological Agri-Food Institute (INTAEX). Avda. Adolfo Suárez s/n, 06071. Badajoz. Spain \\ bAnalytical Chemistry Department. University of Extremadura. Spain \\ ${ }^{c}$ Vegetal Biology, Ecology and Soil Sciences Department. University of Extremadura. Spain \\ Corresponding author: jacinto.sanchez@juntaextremadura.es
}

Submitted: 31 May 2013; Accepted: 9 September 2013; Published on line: 13/02/2014

\begin{abstract}
SUMMARY: The characterization of olive oils from seven representative fruit varieties (Arbequina, Carrasqueña, Corniche, Manzanilla Cacereña, Morisca, Picual, and Verdial de Badajoz) from the southwest of Spain is carried out according to antioxidant capacity of the phenolic fraction and oxidative stability in different ripening stages. Antioxidant capacity is measured through the reduction of a 2,2'-azino-bis-3-ethylbenzthiazoline-6-sulphonic acid radical cation previously oxidized with peroxidase/hydrogen peroxide. The decrease in absorbance at $730 \mathrm{~nm}$ at $3 \mathrm{~min}$ was measured. Values like Trolox Equivalents Antioxidant Capacity and oxidative stability varied from 0.6 to $2.5 \mathrm{mmol}$ Trolox $\cdot \mathrm{kg}^{-1}$ oil and 28.3 to 170.9 hours Rancimat respectively. The best positive correlation between total phenolic compounds and antioxidant capacity were in the Carrasqueña and Arbequina varieties. The rest showed moderated correlations. Correlation between antioxidant capacity and oxidative stability was found in a range from 0.66 to 0.97 , depending on varieties.
\end{abstract}

KEYWORDS: ABTS radical cation; Antioxidant capacity; Olive oil; Oxidative stability; Phenolics

RESUMEN: Capacidad antioxidante de la fracción fenólica de aceites de variedades de aceitunas del sur-oeste de España y su efecto sobre la estabilidad oxidativa. Se caracterizaron Aceites de Oliva Virgen procedentes de siete variedades de aceitunas (Arbequina, Carrasqueña, Corniche, Manzanilla Cacereña, Morisca, Picual y Verdial de Badajoz) representativas del sur-oeste de España de acuerdo a la capacidad antioxidante de su fracción fenólica y a su estabilidad oxidativa, en diferentes estados de maduración. La capacidad antioxidante se midió por la disminución de absorbancia a $730 \mathrm{~nm}$, producida por la reducción del radical ácido 2,2'azino-bis-3-etilbenzotiazolin-6-ácido sulfónico, a $3 \mathrm{~min}$ del inicio de la reacción en presencia del extracto fenólico. Los valores de capacidad antioxidante y de estabilidad oxidativa variaron de 0,6 hasta 2,5 mmol Trolox $\cdot \mathrm{Kg}^{-1} \mathrm{y}_{\mathrm{de}} 28,3 \mathrm{hasta}$ 170,9 horas respectivamente. La mejor correlación entre los compuestos fenólicos y la capacidad antioxidante se observó para las variedades Carrasqueña y Arbequina. Por otro lado, la correlación entre la capacidad antioxidante y la estabilidad oxidativa se encontró dentro de un rango entre 0,66-0,97 dependiendo de la variedad.

PALABRAS CLAVE: Aceite de oliva; Capacidad antioxidante; Cation radical ABTS; Compuestos fenólicos; Estabilidad oxidativa

Citation/Cómo citar este artículo: Franco MN, Galeano-Díaz T, Sánchez J, De Miguel C, Martín-Vertedor D. 2014. Antioxidant capacity of the phenolic fraction and its effect on the oxidative stability of olive oil varieties grown in the southwest of Spain. Grasas Aceites 65 (1): e004. doi: http://dx.doi.org/10.3989/gya.051513

Copyright: (C) 2014 CSIC. This is an open-access article distributed under the terms of the Creative Commons Attribution-Non Commercial (by-nc) Spain 3.0 Licence. 


\section{INTRODUCTION}

The Mediterranean diet includes the consumption of noticeable amounts of extra virgin olive oil, EVOO. To be classified as EVOO, the oil must be only obtained from the fruit of the olive tree by mechanical or other physical means under conditions that do not lead to alteration in the oil and without any other treatment than washing, decantation, centrifugation, or filtration (EC Reg. 1513/2001).

Epidemiological data show that a Mediterranean diet significantly reduces the incidence of cardiovascular disease and cancer, which suggests a characteristic role of the southern European diet, where EVOO is the major source of fatty acids. Also, VOO naturally presents a group of minor components, phenolic compounds, with a high antioxidant capacity and important because of their nutritional and sensorial interests. It has been suggested that the high concentration of phenolic compounds in olive oil may contribute to the healthy action of the Mediterranean diet (PaivaMartins et al., 2010). The antioxidant capacity of phenols and other compounds present in oils has been widely studied by several authors (Morelló et al., 2005; Arslan and Schreiner, 2012). Phenolic compounds continue to be an investigation aim as a consequence of their fundamental chemical and antioxidant properties. Several researchers have used the ABTS radical method. This proposal uses the following approach: a synthetic colored radical is generated and the capacity of a biological sample to reduce the radicals is measured by spectrophotometry, making use of an appropriate standard to quantify the antioxidant capacity. This method is one of the most commonly applied and it is considered as a highly sensitivity, practical and fast method. On the other hand, the phenolic compounds are reported as molecules which significantly prevent the oxidation of olive oil even at low concentrations (Esti et al., 2009) because they possess antioxidant capacity. Oxidative stability is a central parameter in the estimation of EVOO quality, since the oxidative degeneration is the main cause of its damage (Del Carlo et al., 2004; Bendini et al., 2007). Nevertheless the oxidation process can be delayed by antioxidants that enhance oxidative stability by preventing the propagation of lipid peroxidation or removing free radicals. In addition, the oil antioxidant content is not constant; it depends on the cultivar, fruit ripening stage, agroclimatic conditions and olive growing techniques (Beltrán et al., 2000; Uceda and Hermoso, 2001; Tovar et al., 2003).

The European Union dominates the world production of olive oil $(>70 \%)$, and it is the largest consumer. Spain is the country with the highest production of olive oil in Europe (54\%) and Spanish olive oils have been recognized as high quality. Olive oil is considered one of the most important Spanish products. One of the southwest Spanish regions, Extremadura, has made a great effort to increase its production of $\mathrm{VOO}$ in recent years, and is now the third community of Spain in this sense. For that reason, the aim of this work was to evaluate the antioxidant capacity of the phenolic fraction of olive oils obtained from the seven olive varieties most representative of the southwest of Spain (Arbequina, Carrasqueña, Corniche, Manzanilla Cacereña, Morisca, Picual, and Verdial de Badajoz) and examine the relationship between total phenolic compound contents and oxidative stability at different stages of maturation.

\section{MATERIAL AND METHODS}

\subsection{Samples}

The study was carried out in an experimental olive (Olea europaea L.) cultivar maintained within the limits of the olive-growing area "Tierra de Barros" by the Researcher Center "Finca La Orden" (Badajoz, Spain) during the olive season 2011/12. The UTM coordinates of the cultivar were $x=702192.29, y=4303406.71$. The climate of the area is Mediterranean; the average annual rainfall was $404 \mathrm{~mm}$, mostly distributed outside of a 4-month summer drought period. The olive orchard was composed of fifteen-year-old olive trees (plantation frame $6 \times 6 \mathrm{~m}^{2}$ ) of seven varieties predominate in the southwest of Spain: Arbequina, Carrasqueña, Corniche (sinonim Cornicabra variety), Manzanilla Cacereña, Manzanilla Sevillana, Picual, and Verdial de Badajoz. The soil at the experimental orchard was a sandy loam (depth $2 \mathrm{~m}$ ). The orchard was managed by drip irrigation, with linear irrigation scheduling of $3582 \mathrm{~cm}^{3}$ water.ha ${ }^{-1}$ from 15 May to 18 November and no tillage conditions; weeds were controlled with post-emergence herbicides. Note that the fact of getting all the test samples from the same experimental olive grove allowed us to study the effect of the variables "variety" and "maturity stage" on the minor components of the olive oil elaborated from fruits developed in the same geographical area, under the same agronomic and pedoclimatic conditions. In our experiments, we used a statistical design which is based on randomized blocks with three replicates for each variety. Each elementary block consisted of three olive trees. We studied the effect of different olive varieties in analytical parameters, along with the evolution of these parameters throughout the stage of maturation. A total of 63 samples of olives were handpicked in perfect sanitary conditions. The olive samplings were carried out in the morning, taking random samples in different parts of the central area of the olive tree, 
assuming a total of $6 \mathrm{~kg}$ per variety and maturation. The samples were collected at three maturation stages (green, spotted, and ripe). The index of ripeness (IR) of the olives was calculated using the subjective evaluation of color of the skin and flesh, as was proposed by Uceda and Frías (1975). After harvesting, the olive fruit samples were immediately transported to the laboratory in ventilated storage trays to avoid compositional changes. The oil was extracted within $24 \mathrm{~h}$.

Oil samples were obtained using the Abencor grinding system (Abengoa SA, Sevilla, Spain) (Martínez et al., 1975). Olives were crushed with a hammer mill and were slowly beaten for $30 \mathrm{~min}$ at $28{ }^{\circ} \mathrm{C}$. Then the obtained paste was centrifuged at $3500 \mathrm{rpm}$ for $2 \mathrm{~min}$. The oil was separated by decantation and was stored in dark in amber-colored glass bottles at $4{ }^{\circ} \mathrm{C}$ until analysis (within 1 month).

\subsection{Chemicals}

The Folin-Ciocalteau reagent, caffeic acid, and sodium carbonate used for polyphenolic content determination were provided by Panreac (Barcelona, Spain). For the ABTS method, the standard antioxidant used was 6-hydroxy-2,5,7,8tetramethyl-chroman-2-carboxylic acid (Trolox) from Sigma-Aldrich (Steinheim, Germany). 2,2'azobis-(3-ethylbenzothiazoline-6-sulfonic acid was from Fluka Chemicals (Madrid, Spain).

\section{Instruments}

A UV-Vis spectrophotometer model HP8453 (Agilent, Madrid, Spain) was used for the ABTS assays and determination of the total polyphenol contents. The ABTS assay was measured by Biochemical Analysis software. The oxidative stability of the oil was assessed in a 743 Rancimat (Metrohm, Herisau, Switzerland) eight-channel oxidative stability instrument.

\subsection{Analytical methods}

\subsubsection{Antioxidant capacity assays}

Sample preparation: According the slightly modified method of Mateos et al. (2001), a sample of VOO was weighed $(2.5 \mathrm{~g})$ and dissolved in $6 \mathrm{~mL}$ of n-hexane. A diol-bonded phase cartridge (500 mg Supelco Co., Bellefonte, PA) was placed in a vacuum elution apparatus and conditioned with $6 \mathrm{~mL}$ of methanol and $6 \mathrm{~mL}$ of $\mathrm{n}$-hexane. The oil solution was applied to the column, and the solvent was removed while the interesting compounds were retained in the solid phase. After this, it was washed with $6 \mathrm{~mL}$ of $\mathrm{n}$-hexane $(2 \times 3 \mathrm{~mL})$ and $4 \mathrm{~mL}$ of $n$-hexane/ethyl acetate $(85: 15, \mathrm{v} / \mathrm{v})$. The phenolic compounds were eluted with $15 \mathrm{~mL}$ of methanol and the solvent was evaporated in a rotary evaporator at room temperature and a low speed until dryness. The phenolic residue was dissolved in $2 \mathrm{~mL}$ of methanol.

ABTS assay: The radical scavenging capacity of the oil samples was assessed by the ABTS method (Cano et al., 1998; Cano et al., 2000). To generate the ABTS radical cation ABTS was treated with the enzyme system peroxidase (POD)/hydrogen peroxide $\left(\mathrm{H}_{2} \mathrm{O}_{2}\right)$ in acidified ethanol and stored in the dark for 12-16 hours. When the radical was formed, $1 \mathrm{~mL}$ of $\mathrm{ABTS}^{-+}$was mixed with $20 \mu \mathrm{L}$ of phenolic extract, and the absorbance was measured at $730 \mathrm{~nm}$ for six minutes. This procedure was applied to a variable concentration of Trolox and the absorbance decrease was taken as an analytical signal to obtain the calibration line. The results corresponding to phenolic fractions were expressed as TEAC (Trolox Equivalent Antioxidant Capacity) values, mmol Trolox $\cdot \mathrm{kg}^{-1}$ oil.

\subsubsection{Oxidative stability}

The oxidative stability of the examined oils was assessed in a 743 Rancimat (Metrohm, Herisau, Switzerland) eight-channel instrument (Gutiérrez, 1989). $2.5 \mathrm{~g}$ of oil were placed in each of the Rancimat channels. A continuous air stream was introduced through the oil solution to $10 \mathrm{~L} \cdot \mathrm{h}^{-1}$ and the system temperature was established at $100{ }^{\circ} \mathrm{C}$. Changes in conductivity were caused by the formation of volatile organic acids, mainly formic acid and were measured automatically and continuously. The peroxidation curve was recorded, and the inflection point was selected as the induction time (IT, expressed in hours). A high IT value indicates oxidative stability in the sample.

\subsubsection{Determination of total polyphenol contents}

The total polyphenol contents in VOO were determined according to the Folin-Ciocalteau colorimetric method, using caffeic acid as a standard (Montedoro et al., 1992). Each sample was prepared in duplicate and quantification was carried out on the basis of the external standard calibration curve of caffeic acid whose linearity ranged from 5 to $75 \mathrm{mg} \cdot \mathrm{L}^{-1}$. The results of polyphenol contents in the VOO samples are expressed as caffeic acid equivalent (CAE), in $\mathrm{mg} \cdot \mathrm{kg}^{-1}$ oil.

\subsubsection{Statistical analysis}

The results are expressed as mean values and standard deviations. The data were statistically analyzed by ANOVA and Duncan's multiple range 
tests. Statistical significance was accepted at a level of $\mathrm{p}<0.05$. The SPSS 18.0 software (SPSS Inc., Chicago, IL, USA) was used for variance analysis (ANOVA) and linear regression analyses.

\section{RESULTS AND DISCUSSION}

\subsection{Antioxidant capacity of the phenolic fraction of VOO}

The antioxidant capacity of the phenolic fraction of the VOO from seven Extremadura olive varieties is presented in Table 1. The results are expressed in TEAC. The absorbance spectrum of radical ABTS generated by the enzyme system peroxidase (POD)/ hydrogen peroxide $\left(\mathrm{H}_{2} \mathrm{O}_{2}\right)$ and dissolved in acidified ethanol shows different maximum levels at 414, 730 and $873 \mathrm{~nm}(\operatorname{Re}$ et al., 1999). The method is based on the measurement of the reduction in the radical cation that is shown by the decrease of the absorbance at $730 \mathrm{~nm}$ and the discoloration of the $\mathrm{ABTS}^{\cdot+}$. Samaniego et al. (2007) showed that the ABTS method was the best to measure the antioxidant capacity of olive oil, giving good results of reproducibility and with acceptable correlation coefficients.

For this study, a $730 \mathrm{~nm}$ wavelength has been selected since good sensitivity and reliability is achieved (Calvo et al., 2010). We checked the stability of the dissolution of the ABTS radical formed by the absorbance measurements at $730 \mathrm{~nm}$ at intervals of 3 hours. Re et al. (1999) indicated that the ABTS radical was stable for more than two days when stored in the dark at room temperature. However, our results showed that, under the same conditions, the absorbance varied during the first 18 hours, and subsequently it was significantly maintained over

TABle 1. Antioxidant capacity, oxidative stability, and total phenolic compounds of seven varieties of VOOs obtained from fruits at three stages of ripening

\begin{tabular}{|c|c|c|c|c|}
\hline Ripening index & Variety & $\begin{array}{c}\text { Antioxidant } \\
\text { Capacity ABTS, mmol } \\
\text { Trolox } \cdot \mathrm{kg}^{-1} \text { oil }\end{array}$ & Oxidative Stability hours & $\begin{array}{l}\text { Total phenolic compound } \\
\text { mg CAE } \cdot \mathrm{kg}^{-1} \cdot 10\end{array}$ \\
\hline \multirow{7}{*}{ Green $\mathrm{RI}<2$} & Arbequina & $1.7 \pm 0.2^{\mathrm{ab} \mathrm{B}}$ & $68.5 \pm 4.4^{\mathrm{ab} \mathrm{B}}$ & $40.9 \pm 5.4^{\mathrm{a} \mathrm{B}}$ \\
\hline & Carrasqueña & $2.5 \pm 0.4^{\mathrm{c} \mathrm{B}}$ & $163 \pm 25^{\mathrm{d} \mathrm{B}}$ & $120.3 \pm 15.3^{\mathrm{d} \mathrm{B}}$ \\
\hline & Corniche & $2.0 \pm 0.1^{\mathrm{b} \mathrm{B}}$ & $171 \pm 13^{\mathrm{dC}}$ & $70.8 \pm 9.6^{\mathrm{cC}}$ \\
\hline & Manzanilla Cacereña & $1.6 \pm 0.1^{\mathrm{a} \mathrm{B}}$ & $140.0 \pm 7.7^{\text {с в }}$ & $70.7 \pm 7.3^{\text {с в }}$ \\
\hline & Morisca & $1.9 \pm 0.4^{\mathrm{ab} \mathrm{B}}$ & $54.7 \pm 7.2^{\mathrm{ac}}$ & $53.7 \pm 7.7^{\mathrm{abc}}$ \\
\hline & Picual & $1.7 \pm 0.1^{\mathrm{ab} \mathrm{B}}$ & $151.9 \pm 4.8^{\mathrm{cd} \mathrm{B}}$ & $67.1 \pm 3.4^{\mathrm{bc} \mathrm{C}}$ \\
\hline & Verdial de Badajoz & $2.0 \pm 0.1^{\mathrm{c} \mathrm{C}}$ & $47.6 \pm 2.1^{\mathrm{a} \mathrm{B}}$ & $55.9 \pm 7.9^{\mathrm{abc} \mathrm{B}}$ \\
\hline \multirow{7}{*}{ Spotted RI=2-3 } & Arbequina & $1.2 \pm 0.1^{\mathrm{a} \mathrm{B}}$ & $49.0 \pm 1.0^{\mathrm{a} \mathrm{A}}$ & $23.4 \pm 2.4^{\mathrm{a} \mathrm{A}}$ \\
\hline & Carrasqueña & $1.7 \pm 0.3^{\mathrm{bc} \mathrm{A}}$ & $94 \pm 2.5^{\mathrm{b} \mathrm{A}}$ & $62.9 \pm 16.2^{\mathrm{bA}}$ \\
\hline & Corniche & $1.9 \pm 0.1^{\mathrm{cB}}$ & $150 \pm 10^{\text {с в }}$ & $49.7 \pm 5.5^{\text {b в }}$ \\
\hline & Manzanilla Cacereña & $1.2 \pm 0.3^{\mathrm{a} \mathrm{AB}}$ & $80 \pm 10^{\mathrm{bA}}$ & $21.7 \pm 13.2^{\mathrm{a} \mathrm{A}}$ \\
\hline & Morisca & $1.2 \pm 0.2^{\mathrm{a} \mathrm{A}}$ & $28.3 \pm 4,3^{\mathrm{aA}}$ & $13.0 \pm 3.9^{\mathrm{a} \mathrm{A}}$ \\
\hline & Picual & $1.8 \pm 0.1^{\mathrm{bc} \mathrm{B}}$ & $148.3 \pm 2.8^{\mathrm{c} \mathrm{B}}$ & $59.3 \pm 2.2^{\mathrm{b} \mathrm{B}}$ \\
\hline & Verdial de Badajoz & $1.5 \pm 0.2^{\mathrm{ab} \mathrm{B}}$ & $27.9 \pm 5.8^{\mathrm{aA}}$ & $24.5 \pm 5.2^{\mathrm{aA}}$ \\
\hline \multirow{7}{*}{ Ripe $\mathrm{RI}>3$} & Arbequina & $0.6 \pm 0.1^{\mathrm{a} \mathrm{A}}$ & $45.5 \pm 3.9^{\mathrm{bc} \mathrm{A}}$ & $16.0 \pm 3.2^{\mathrm{a} \mathrm{A}}$ \\
\hline & Carrasqueña & $1.4 \pm 0.3^{\mathrm{c} \mathrm{A}}$ & $84 \pm 17^{\mathrm{eA}}$ & $46.1 \pm 19.6^{\mathrm{cA}}$ \\
\hline & Corniche & $1.3 \pm 0.1^{\mathrm{c} \mathrm{A}}$ & $113.7 \pm 3.2^{\mathrm{f} \mathrm{A}}$ & $29.9 \pm 3.8^{\mathrm{ab} \mathrm{A}}$ \\
\hline & Manzanilla Cacereña & $0.9 \pm 0.1^{\mathrm{bA}}$ & $70 \pm 13^{\text {de A }}$ & $20.1 \pm 8.6^{\mathrm{aA}}$ \\
\hline & Morisca & $0.8 \pm 0.0^{\mathrm{b} \mathrm{A}}$ & $30.6 \pm 2.7^{\mathrm{ab} \mathrm{B}}$ & $23.2 \pm 0.7^{\text {а в }}$ \\
\hline & Picual & $1.3 \pm 0.1^{\mathrm{c} \mathrm{A}}$ & $123.4 \pm 4.7^{\mathrm{f} \mathrm{A}}$ & $41.9 \pm 0.5^{\mathrm{bc} \mathrm{A}}$ \\
\hline & Verdial de Badajoz & $0.7 \pm 0.1^{\mathrm{ab} \mathrm{A}}$ & $24.4 \pm 5.1^{\mathrm{a} \mathrm{A}}$ & $18.3 \pm 4.9^{\mathrm{aA}}$ \\
\hline
\end{tabular}

$\mathrm{CAE}$, caffeic acid equivalents. Results are expressed as mean $\pm \mathrm{SD}$ of three sample replicates. Different small letters in the same maturation stage indicate significant statistical differences among varieties (Duncan's Test, $\mathrm{p}<0.05$ ). Different capital letters in the same column indicate significant statistical differences (Duncan's Test, $\mathrm{p}<0.05$ ) during the maturation stage. 


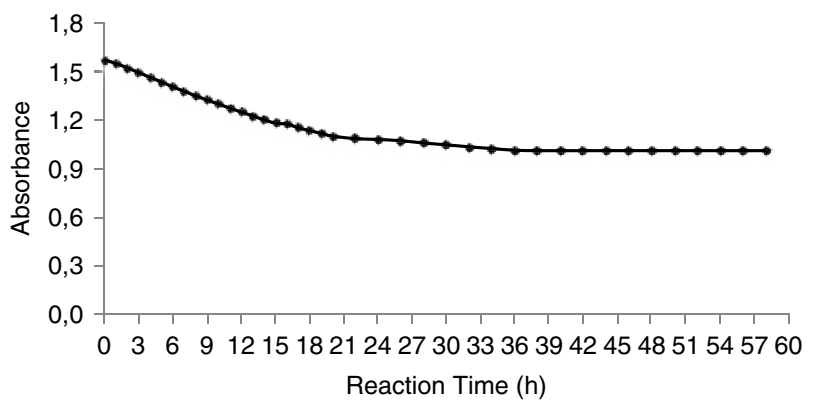

Figure 1. Measurement of ABTS radical stability over time.

the following 42 hours (Figure 1). Therefore, preparation of the radical one day before its utilization is advisable.

On the other hand, Arnao (2000) indicated that it is a very reliable method, although the values of antioxidant capacity might depend on the time chosen to perform the measurement. In this sense, Re et al. (1999) indicated 4 min as the most appropriate time. However, Sellappan et al. (2002) suggested 6 minutes for standards and $7 \mathrm{~min}$ for pure compounds in plant extracts or foods, whereas Calvo et al. (2012) considered optimal a measurement time of 20 minutes after the start of the reaction in samples of extra virgin olive oil. In this work, the kinetic curves Absorbance-time, corresponding to the interaction of the ABTS radical cation with Trolox (Figure 2) as a standard compound has been constructed. These results have demonstrated that the $\mathrm{ABTS}^{++}$reduction reaction is complete in about 2 min and absorbance values do not change significantly up to $20 \mathrm{~min}$. The selection of a measurement
TABLE 2. Analytical figures of merit for ABTS method

\begin{tabular}{lc}
\hline Parameters & Trolox \\
\hline Linear regression & $\mathrm{y}=0.37 \mathrm{x}+0.02$ \\
Determination coefficient $\mathrm{r}^{2}$ & 0.993 \\
$\%$ Linearity & 97.9 \\
LOD $^{\mathrm{a}}$ ppm & 0.05 \\
$\mathrm{LOD}^{\mathrm{b}} \mathrm{ppm}$ & 0.10 \\
LOQ $^{\mathrm{c}} \mathrm{ppm}$ & 0.17 \\
\hline
\end{tabular}

a Limit of detection, Long and Winefordner method

${ }^{b}$ Limit of detection, Clayton et al. method $\alpha=\beta=0.05$

'Limit of quantification, from LOD $\times 3.33$

time of $3 \mathrm{~min}$ is enough to ensure repeatability since the reaction has been completed successfully. This proposal is very time saving because it enables the measurement of a large number of samples in a short time.

The analytical figures of merit corresponding to this method are shown in Table 2. A linear relationship was observed between the analytical signals (loss in absorbance) and the concentrations of Trolox. The regression coefficient was 0.993 . The slope of this plot was $0.37 \mathrm{~kg} \cdot \mathrm{mmol}^{-1}$. The limit of detection (LODs), calculated with the ACOC software package, was 0.05 by the Long and Winefordner method (1983) and $0.10 \mathrm{mmol} \cdot \mathrm{kg}^{-1}$ by the method of Clayton et al. (1987). The limit of quantification (LOQ) was calculated as LOD (Long and Winefordner) $\mathrm{x} 3.33$, was $0.16 \mathrm{mmol} \cdot \mathrm{kg}^{-1}$. The calibration curve was utilized to evaluate the

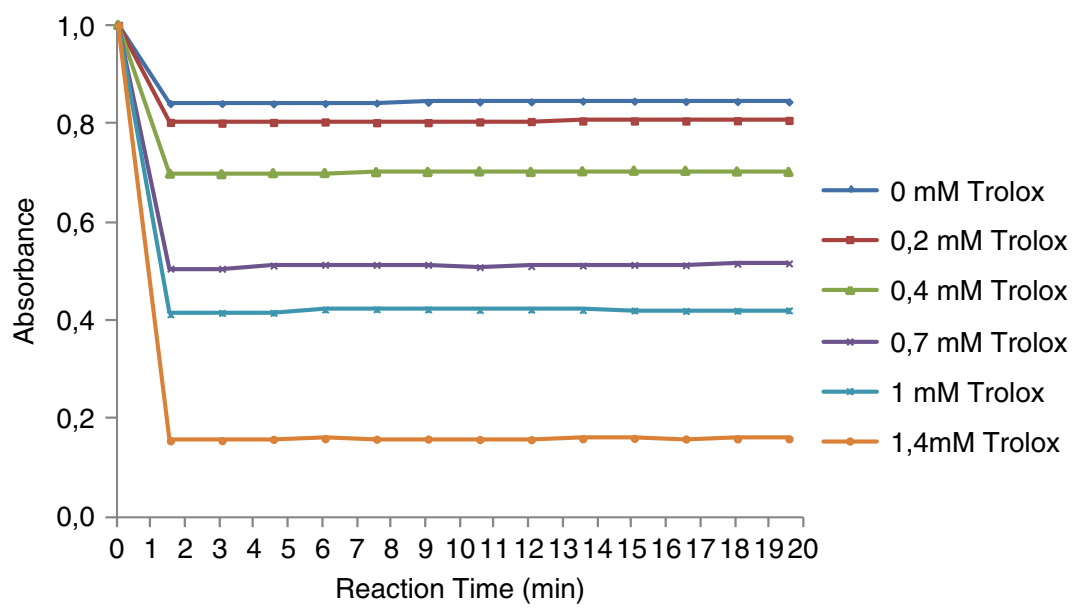

Figure 2. The effect of reaction time on the decrease in $\mathrm{ABTS}^{\circ+}$ absorbance value for the reference standard Trolox. 
antioxidant capacity of various EVOOs examined and the results are shown in Table 1. In general, the antioxidant capacity presents a trend to decrease as the same time that olive ripening advances in the seven olive oil varieties studied. This trend was significant in all maturation stages of the Verdial de Badajoz (2.0-0.7 mmol $\left.\cdot \mathrm{kg}^{-1}\right)$ variety. On the other hand, Corniche and Picual varieties showed similar antioxidant capacities from the green to spotted stages and from this stage, the values of antioxidant capacity decreased significantly until the ripe maturation stage. However, the TEAC values of Carrasqueña, Manzanilla Cacereña, and Morisca varieties decreased significantly from the green to the spotted stage, and from this stage the antioxidant capacity remained constant until the ripe maturation stage. In general, vegetable oils contain a large variety of substances with antioxidant properties which include free radical scavengers, reducing agents, complexing agents for pro-oxidant metals, and quenchers of the singlet oxygen formation (Gorinstein et al., 2003). The methanol soluble phase of vegetable oils contains most of the phenolic antioxidant; it is also called the polar fraction (Valavanidis et al., 2004). There is no information on the trend of the antioxidant capacity as the olive ripening advances in the literature.

The examined oils could be classified into different groups according to their antioxidant capacity from the results in Table 1 . The first group, with lower TEAC values, would include the Arbequina, Manzanilla Cacereña, and Morisca varieties, while higher TEAC values were obtained for the Carrasqueña and Corniche varieties in all stages of maturation. The Picual and Verdial de Badajoz varieties did not show a clear grouping according to their antioxidant capacity. The Corniche and Carrasqueña varieties had higher antioxidant capacities, 2 and $2.5 \mathrm{mmol}$ Trolox $\cdot \mathrm{kg}^{-1}$ oil, respectively, in the green stage. The Verdial de Badajoz variety presented antioxidant capacity values in the green stage of maturation similar to the Carrasqueña variety, while it is placed in the second group in the spotted and ripe stages of maturation. Our results are in agreement with those found in the literature. Therefore, Calvo et al. (2012) presented values of total antioxidant capacity of $1.35 \mathrm{mmol}$ Trolox $\cdot \mathrm{kg}^{-1}$ oil in Morisca and Picual monovarietal oils in the ripe stage, however they obtained values of $0.83 \mathrm{mmol}$ Trolox $\cdot \mathrm{kg}^{-1}$ oil in a commercial oil of the Picual variety. Also, Samaniego et al. (2007) reported values of $1.00 \mathrm{mmol}$ Trolox $\mathrm{kg}^{-1}$ oil in EVOO from the Picual variety, in the years 2003/2004. Montedoro et al. (1992) found low values of antioxidant capacity $\left(0.63 \mathrm{mmol}\right.$ Trolox $\cdot \mathrm{kg}^{-1}$ oil $)$ in the Cornicabra variety, similar to those obtained in our study for group of varieties with lower antioxidant capacities in the ripe stage.

\subsection{Oxidative stability in VOOs}

A significant decrease in the time of induction from the green to spotted olives stage of maturation has been found for most of the studied varieties, except for the Picual variety which is maintained constant. From this state of maturation, the change in oxidative stability is, in general, less pronounced until the ripe stage of maturation (Table 1). Salvador et al. (2001) reported that oxidative stability decreased slightly as the olive ripening advanced, although the trend was not clear and in some cases there was a small increase with fruit maturity.

Within each variety, differences in the stability of the oil were observed for different stages of ripeness, and oxidative stability values are strongly dependent on each olive variety (Oueslati et al., 2009). The range of values of oxidative stability was from 24.4 to 47.6 and from 113.7 to 170.9 hours for the Verdial de Badajoz and Corniche varieties, respectively (Table 1). In all the varieties of oils produced, differences were observed for the various oils examined when analyzing the influence of olive maturity on oxidative stability. The stability of oils from the Morisca variety decreased rapidly $(48.26 \%)$, while the Arbequina, Corniche and Verdial de Badajoz varieties only slightly decreased (about $20 \%$ ) from the green to spotted stage of maturation. The oxidative stability was constant in the Picual variety until the spotted stage of maturation and from that point it decreased until the ripe stage of maturation $(16.8 \%)$. The highest oxidative stability was for the Carrasqueña and Corniche varieties in the green stage of maturation (Table 1) with statistically significant differences compared to the rest of the varieties. The lowest oxidative stability was presented in Arbequina, Morisca, and Verdial de Badajoz. The Manzanilla Cacereña variety presented intermediate values in all the stages of maturation. In addition, the Corniche and Picual varieties presented the longest induction times throughout the different stages of maturation. These results are in agreement with those obtained by other researchers (Salvador et al., 2001; Pérez-Arquillué et al., 2003; Aguilera et al., 2005; Baccouri et al., 2008; Fuentes et al., 2008).

\subsection{Contribution of the phenolic fraction to antioxidant capacity and oxidative stability in VOOs}

The Trolox equivalent antioxidant capacity is strongly related to the concentration of phenolic compounds in olive oil. We can observe that those varieties which presented the highest contents in phenolic compounds (Table 1) like Carrasqueña, also had the highest antioxidant capacity. However, the varieties with minor contents, like the Arbequina and Morisca varieties, 
were the varieties which had the lowest antioxidant capacities. In general terms, a tendency to decrease the total phenolic content was observed in all the varieties analyzed during ripening (Table 1). This trend was more pronounced in the Morisca variety from the green to the spotted stage. Phenolic content showed the same evolution but with a less marked decrease in the concentration of phenolic compounds in the rest of the varieties. Regarding oils from the Corniche and Picual varieties, the concentration of phenolic compounds significantly decreased in all stages of maturation of the olives, while from the Morisca variety, the oils significantly increased up to the ripe stage. Previous studies have described a general decrease in total phenolic compounds as fruit ripening advanced, while different trends were observed when examining specific compounds (Dugo et al., 2004; Agati et al., 2005). Oueslati et al. (2009) did not find clear differences between the content of phenolic compounds and the maturation index. On the other hand, the total phenol contents showed significant differences $(p<0.05)$ among the different varieties (Table 1). The range of values of total phenolic compounds obtained in all the varieties from Extremadura varied from 129.8 to $1203.3 \mathrm{mg} \cdot \mathrm{kg}^{-1}$. The lowest values found in the green stage corresponded to the Arbequina variety whose concentration was $409.4 \mathrm{mg} \cdot \mathrm{kg}^{-1}$, while the Carrasqueña variety had the greatest concentration in phenolic compounds with values of $1203.3 \mathrm{mg} \cdot \mathrm{kg}^{-1}$ in the same stage. The total phenolic compounds in olive oil showed a positive linear correlation with antioxidant capacity (Figure 3 ), hence an increase in the concentration of total phenolic compounds causes an increase in antioxidant capacity. The best correlation between total phenolic compounds and antioxidant capacity was found in the Carrasqueña $\left(r^{2}=0.97\right)$ and Arbequina $\left(r^{2}=0.90\right)$ varieties and the worst for the Morisca $\left(\mathrm{r}^{2}=0.48\right)$ variety by the ABTS method. The rest of the varieties presented moderated correlations $\left(\mathrm{r}^{2}=0.66\right.$ to 0.77$)$.

The correlation between total phenolic content and antioxidant capacity has been widely studied in different foodstuffs: fruit and vegetables (Kedage et al., 2007), wine (Fernández-Pachón et al., 2005; Villaño et al., 2006), plants (Velioglu et al., 1998), seeds (Holasova et al., 2002) and olive oil (UbandoRivera et al., 2005; Del Carlo et al., 2004), and it has been shown that a high concentration of total phenol content implies that the antioxidant capacity of that food significantly increases due to its capacity to block free radicals (Gorinstein et al., 2003; Morelló et al., 2005; Baiano et al., 2009). Samaniego et al. (2007) determined that the best correlation between total phenol content and antioxidant capacity was given by the ABTS method $\left(r^{2}=0.89\right)$ in oil samples from the Picual variety from different harvests. At the same time, they found that the olive oil samples studied presented a mean value of $201 \mathrm{mg}$ gallic acid $\cdot \mathrm{kg}^{-1}$ oil $(\mathrm{n}=6)$, a value which is below that of the EVOO samples, revealing a lower content of phenolic compounds, which are bioactive compounds in olive oil with the highest antioxidant capacity (Gorinstein et al., 2003).

On the other hand, it is well known that the behavior observed in oxidative stability, and therefore in oil conservation, is influenced by the content of phenolic compounds (Gutiérrez et al., 1999). Therefore, there must be a correlation between antioxidant capacity and oxidative stability and, indeed, from our results there is a range of correlation between of $0.66-0.97$, depending on the variety (Figure 3). However, very precise relations between stability and the preservation of the oil cannot be established because oxidative stability is determined under the extreme conditions achieved in a Rancimat $\left(100{ }^{\circ} \mathrm{C}\right.$ and oxygen saturation with air flow from $10 \mathrm{~L} \cdot \mathrm{h}^{-1}$ ), while in the conservation of the oil, the supply of oxygen is limited and the temperature is much lower(Certetal., 1999), although this parameter can be useful in order to have a more rigorous understanding of the oxidation capacity and the characteristics of the VOO produced. On the other hand, the effect of concentration on the antioxidant capacity of phenolic compounds has not been fully clarified. Baldioli et al. (1996) observed that the oxidative stability increased linearly with the concentration in olive oil with $1.10 \mathrm{mmol} \cdot \mathrm{kg}^{-1}$ oil of antioxidant capacity while Mateos (2002) showed an increase in oxidative stability until the antioxidant activity reached a concentration of approximately $1 \mathrm{mmol} \cdot \mathrm{kg}^{-1}$ and although the concentration of antioxidants increased the antioxidant capacity remained practically constant.

\section{CONCLUSIONS}

The ABTS method contributed to the characterization of EVOO, from seven varieties of fruits from the southwest of Spain and it has been proven that a 3 min waiting time is enough to reach a reliable value in the measurement of antioxidant activity. This fact is very timely, considering that free radicals are short-lived and that permits the measurement of a large number of samples. Two different groups have been established in the examined oils. The first of them, with lower TEAC values, would include the Arbequina, Manzanilla Cacereña, and Morisca varieties, while the higher TEAC values were obtained for the Carrasqueña and Corniche varieties.

The oxidative stability has also served to characterize VOOs. In this sense, the highest oxidative stability was for the Carrasqueña and Corniche varieties. The lowest oxidative stability was 

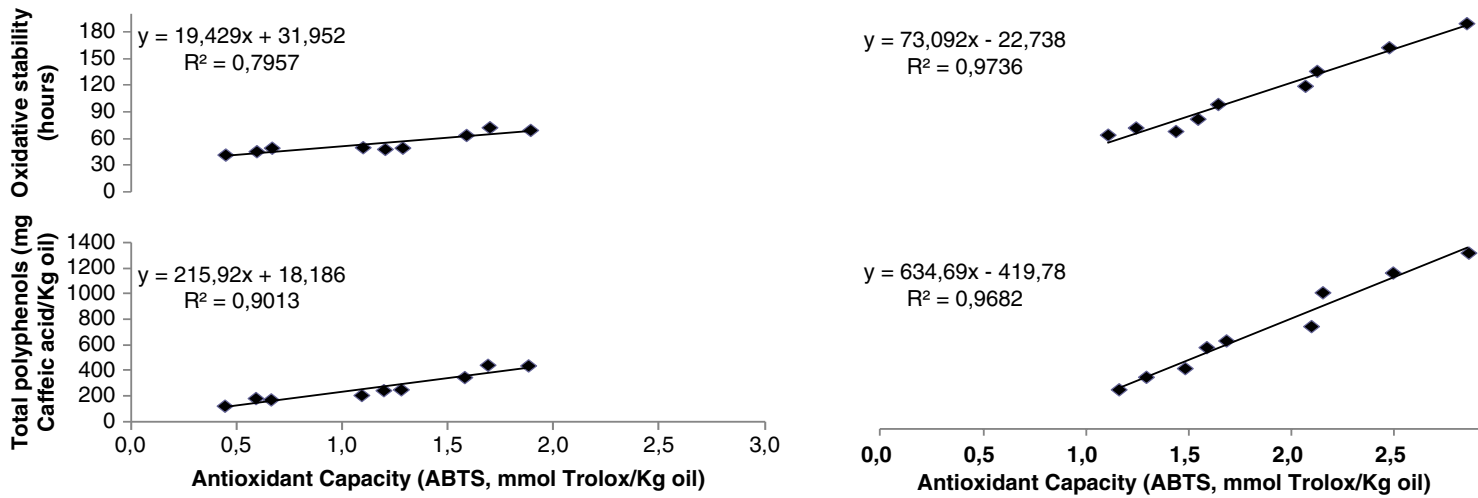

Morisca variety
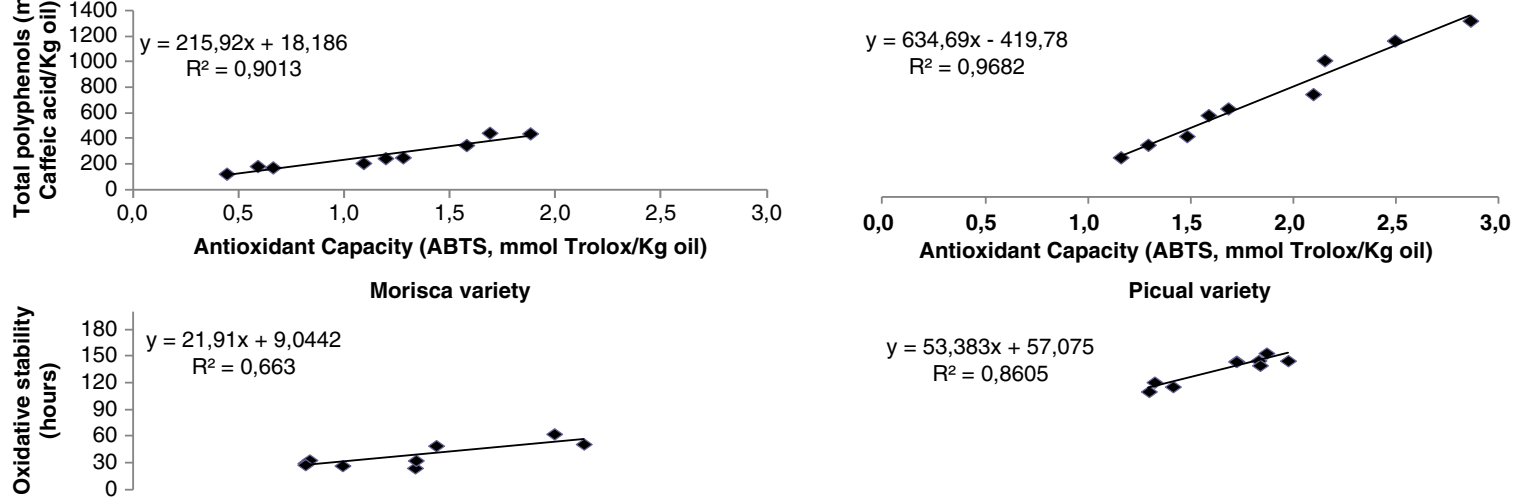

Picual variety

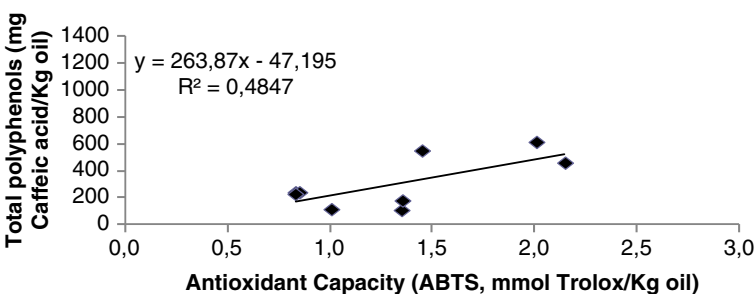

Corniche variety
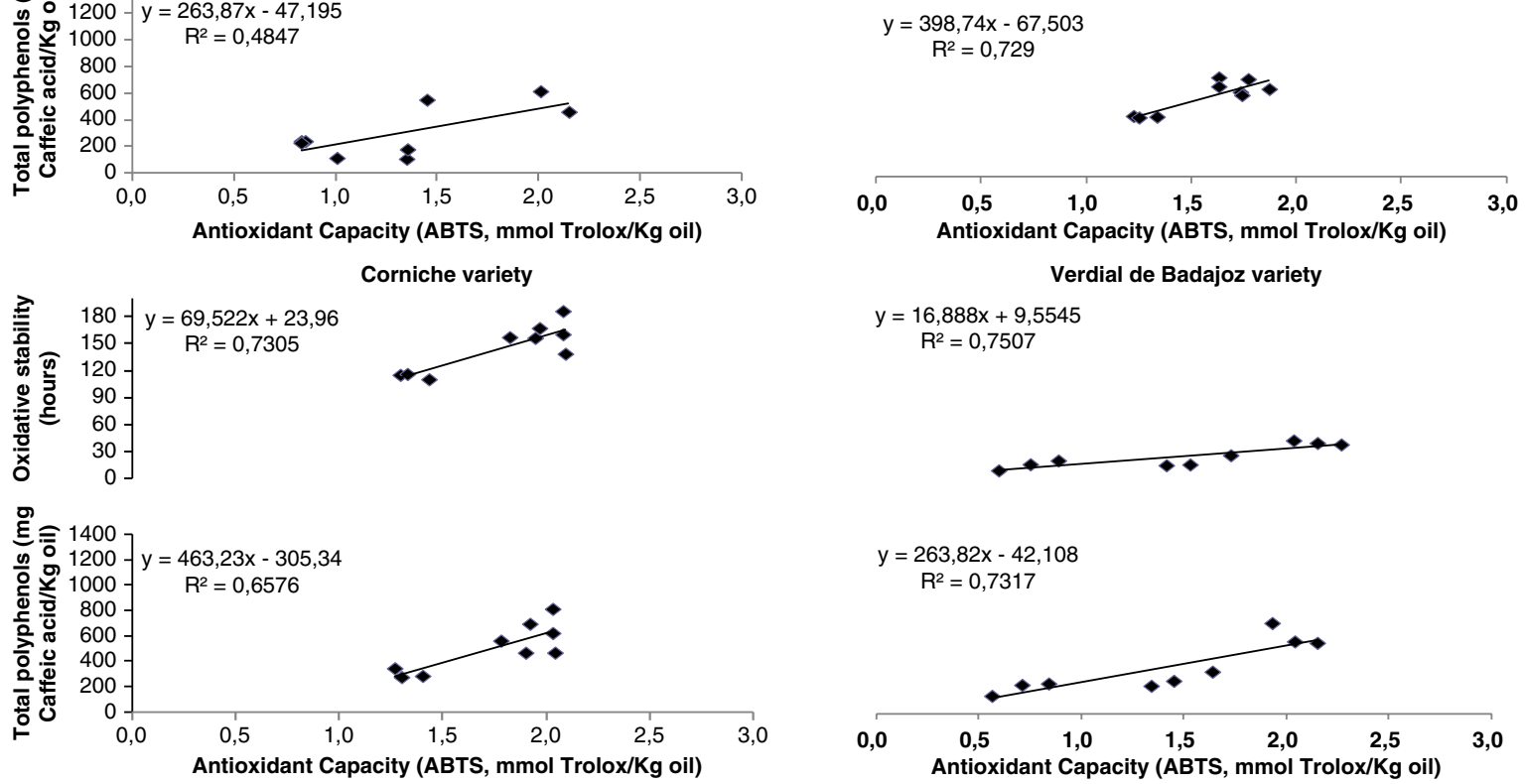

$y=263,82 x-42,108$

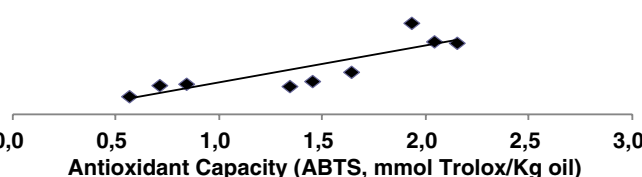

Manzanilla Cacereña variety
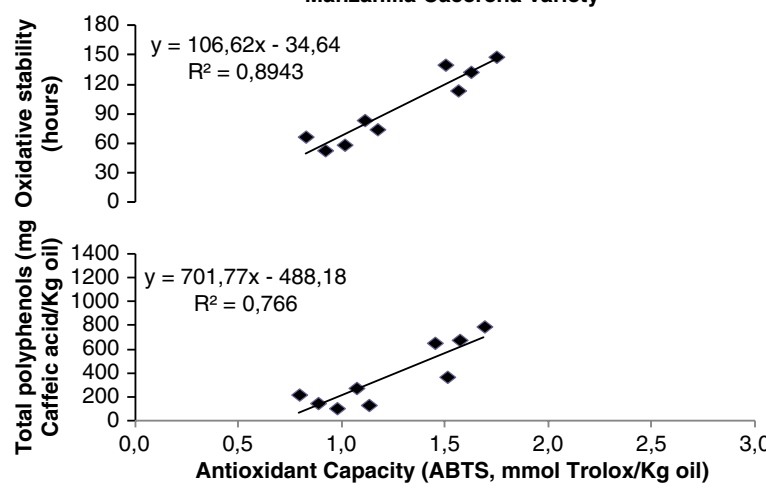

FIGURE 3. Linear correlations between antioxidant capacity and total phenolic compounds and oxidative stability in seven Extremadura varieties of VOOs produced by the Abencor system. 
presented in the Arbequina, Morisca, and Verdial de Badajoz. The Manzanilla Cacereña variety presented intermediate values. The Corniche and Picual varieties presented the longest induction times.

A good correlation was found between antioxidant capacity, total phenolic content and oxidative stability in the seven Extremadura varieties studied throughout the maturity of the fruit, indicating that antioxidant capacity is mainly influenced by the amount of phenolic compounds which greatly contribute to the inhibition of lipid oxidation.

\section{ACKNOWLEDGEMENTS}

This study has been carried out with financial support from the Government of Extremadura (project 6/12). MN. Franco wishes to thank the FSE and the Government of Extremadura for the grant (TEC09072). The authors wish to thank the Research Center "Finca la Orden" for the field experiment varieties and J. Hernández Carretero, J.M. García Ballesteros, and J. Barahona Nogales for their help in the performance of this study.

\section{REFERENCES}

Agati G, Pinelli P, Cortés S, Romani A, Cartelat A, Cerovic ZG. 2005. Nondestructive evaluation of anthocyanins in olive Olea europaea fruits by in situ chlorophyll fluorescente spectroscopy. J. Agric. Food. Chem. 53, 1354-1363.

Aguilera MP, Beltrán G, Ortega D, Fernández A, Jiménez A, Uceda M. 2005. Characterisation of virgin olive oil of Italian olive cultivars: "Frantoio" and "Leccino", grown in Andalusia. Food Chem. 89, 387-391.

Arnao MB. 2000. Some methodological problems in the determination of antioxidant activity using chromogen radicals: a pratical case. Trends Food Sci. Techol. 11, 419-421.

Arslan D, Schreiner M. 2012. Chemical characteristics and antioxidant activity of olive oils from Turkish varieties grown in Hatay province. Scientia Hortic. 144, 141-152.

Baccouri O, Guerfel M, Baccouri B, Cerretani L, Bendini A, Lercker G, Zarrouk M, Daoud D, Miled B. 2008. Chemical composition and oxidative stability of Tunisian monovarietal virgin olive oils with regard to fruit ripening. Food Chem. 109, 743-754

Baiano A, Gambacorta G, Terracone C, Previtali MA, La Notte E. 2009. Characteristics of drupes, phenolic content and antioxidant capacity of Italian olive fruits. J. Food Lipids 16, 209-226.

Baldioli M, Servili M, Perretti G, Montedoro GF. 1996. Antioxidant activity of tocopherols and phenolic compounds of virgin olive oil. J. Am. Oil Chem. Soc. 73, 1589-1593.

Beltrán G, Jiménez A, Aguilera MP, Uceda M. 2000. Análisis mediante HPLC de la fracción fenólica del aceite de oliva virgen de la variedad Arbequina. Relación con la medida de amargor K225 y la estabilidad. Grasas Aceites 215, $320-324$.

Bendini A., Cerretani L., Carrasco-Pancorbo A., GomezCaravaca A.M., Segura-Carretero A., FernandezGutierrez A. 2007. Phenolic molecules in virgin olive oils: A survey of their sensory properties, health effects, antioxidant activity and analytical methods. An over-view of the last decade. Molecules 12, 1679-1719.

Calvo P, Hernández MT, Lozano M, González D. 2010. Microencapsulation of extra-virgin olive oil by spraydrying: Influence of wall material and olive quality. Eur. $J$. Lipid Sci. Technol. 112, 852-858.
Calvo P, Castaño AL, Lozano M, González D. 2012. Influence of the microencapsulation on the quality parameters and shelf-life of extra-virgin olive oil encapsulated in the presence of BHT and different capsule wall components. Food Res. Int. 45, 256-261.

Cano A, Hernández-Ruiz J, García-Cánovas F, Acosta M, Arnao MB. 1998. An end-point method for estimation of the total antioxidant activity in plants material. Phytochem Anal. 9, 196-202.

Cano A, Acosta M, Arnao MB. 2000. A method to measure antioxidant activity in organic media: application to lipophilic vitamins. Redox Rep. 5, 365-70.

Cert A, Alba J, Pérez-Camino MC, Ruiz-Gómez A, Hidalgo F, Moreda W, Moyano MJ, Martínez F, Tubaileh R, Olías JM. 1999. "Influencia de los sistemas de extracción sobre las características y los componentes menores del aceite de oliva virgen extra". Ciencia y Técnica 79, 41-50.

Del Carlo M, Saccheti G, Di Mattia C, Compagnone D, Mastrocola D, Liberatore L, Cichelli A. 2004. Contribution of the phenolic fraction to the antioxidant activity and oxidative stabilite of olive oils. J. Agric. Food. Chem. 52, 4072-4079.

Clayton CA, Hines JW, Elkins PD. 1987. Detection limits with specified assurance probabilities. Anal. Chem. 59, 2506-2514.

Dugo G, Lo Turco V, Pollicino D, Mavrogeni E, Pipitone F. 2004. Caracterización de los aceites de oliva vírgenes sicilianos. Variaciones cualitativas en los aceites de las variedades "Biancolilla", "Nocellara del Belice", "Cerasuola", "Tonda Iblea", y Crastu" dependiendo de las técnicas y el periodo de recolección de las aceitunas. Olivae 101, 44-51.

Esti, M., Contini, M., Moneta, E., Sinesio, F. 2009. Phenolic compounds and temporal

perception of bitterness and pungency in extra virgin olive oils: changes occurring throughout storage. Food Chem. 113, 1095-1100.

Fernández-Pachón MS, Villano D, Troncoso AM, GarcíaParrilla MC. 2005. Antioxidant capacity of plasma after red wine intake in human volunteers. J. Agric. Food. Chem. 53, 5024-29.

Fuentes M, Marín J, De Miguel C, Sánchez J. 2008. Extraction Systems and quality parameters of extra virgin olive oils from the olive-oil producing zone "Tierra de Barros" Extremadura, Spain. Riv. Ital. Sostanze Grasse 85, 48-55.

Gorinstein S, Yamamoto K, Katrich E, Leontowicz H, Lojek A, Leontowicz M, Ciz M, Goshev I, Shalev U, Trakhtenberg S. 2003. Antioxidative properties of Jaffa sweeties and grapefruit and their influence on lipid metabolism and plasma antioxidative potential in rats. Biosci. Biotechnol. Biochem. 67, 907-910.

Gutiérrez F. 1989. Determinación de la estabilidad oxidativa de aceites de oliva vírgenes: comparación entre el método del oxígeno activo A.O.M y el método Rancimat. Grasas Aceites 401, 1-5.

Gutiérrez F, Jiménez B, Ruíz A, Albi A. 1999. Effect of olive ripeness on the oxidative stability of virgin olive oil extraxted from the varieties picual and hojiblanca and on different components involved. J. Agric. Food. Chem. 47, 121-127.

Holasova M, Fiedlerova V, Smrcinova H, Orsak M, Lachman J, Vavreinova S. 2002. Buckwheat - The source of antioxidant activity in functional foods. Food Res. Int. 35, 207-211.

Kedage W, Tilak JC, Dixit GB, Devasagayam TP, Mhatre M. 2007. A study of antioxidant properties of some varieties of grapes Vitis vinifera L. Crit. Rev. Food Sci. Nutr. 472, $175-185$.

Long GL, Winefordner JD. 1983. Limits of Detection: A Closer Look at the IUPAC Definition. Anal. Chem. 55, 712-724.

Martínez JM, Muñoz E, Alba J, Lanzón A. 1975. Informe sobre utilización del Analizador de Rendimientos "Abencor". Grasas Aceites 266, 379-385.

Mateos, R., 2002. Caracterización de componentes fenólicos del aceite de oliva y su relación con la estabilidad oxidativa y el amargo. Tesis Doctoral, Universidad de Sevilla.

Mateos R, Espartero JL, Trujillo M, Rios JJ, León-Camacho M, Alcudia F, Cert A. 2001. Determination of phenols, flavones and lignans in virgin olive oils by solid phase 
extraction and high-performance liquid chromatography with diode array ultraviolet detection. J. Agric. Food. Chem. 49, 2185-2192.

Montedoro G, Servili M, Baldioli M, Miniati E. 1992. Simple and hydrolizable phenolic compounds in virgin olive oil. 1. Their extraction, separation and quantitative and semiquantitative evaluation by HPLC. J. Agric. Food. Chem. 40, 1571-1576.

Morelló JR, Vuorela S, Romero MP, Motilva MJ, Heinonen M. 2005. Antioxidant activity of olive pulp and olive oil phenolic compounds of the Arbequina cultivar. J. Agric. Food. Chem. 53, 2002-2008.

Oueslati I, Anniva C, Daoud D, Tsimidou MZ, Zarrouk M. 2009. Virgin olive oil VOO production in Tunisia: The commercial potential of the major olive varieties from the arid Tataouine zone. Food Chem. 112, 733-741.

Paiva-Martins F, Fernandes J, Santos V, Silva L, Borges F, Rocha S. 2010. Powerful protective role of 3,4-dihydroxyphenylethanol-elenolic acid dialdehyde against erythrocyte oxidativeinduced hemolysis. J. Agric. Food. Chem. 58, 135-140.

Pérez-Arquillué C, Juan T, Valero N, Estopañán G, Ariño A, Conchello P, Herrera A. 2003. Estudio de la calidad del aceite de oliva virgen de Aragón. Grasas Aceites 54, 151-160.

Re R, Pellegrini N, Proteggente A, Pannala A, Yang M, RiceEvans C. 1999. Antioxidants activity applying an improved ABTS radical catión decolorization assay. Free Radical Biol. Med. 26, 1231-7.

Salvador MD, Aranda F, Fregapane G. 2001. Influence of fruit ripening on "Cornicabra" virgin olive oil quality A study of four successive crop seasons. Food Chem. 73, 45-53.

Samaniego C, Troncoso AM, García MC, Quesada JJ, López H, López MC. 2007. Different radical scavenging tests in virgin olive oil and their relation to the total phenol content. Anal. Chem. Acta 593, 103-107.

Sellappan S, Akoh CC, Krewer G. 2002. Phenolic compounds and antioxidant capacity of Georgia-Grown blueberries and blackberries. J. Agric. Food. Chem. 50, 2432-2438.

Tovar MJ, Romero MP, Alegre S, Girona J, Motilva MJ. 2003. Composition and organoleptic characteristics of oil from Arbequina olive Olea europaea L. trees under deficit irrigation. J. Sci. Food Agric. 82, 1755-1763.

Ubando-Rivera J, Navarro-Ocaña A, Valdivia-López MA. 2005. Mexican lime peel: Comparative study on contents of dietary fibre and associated antioxidant activity. Food Chem. 89, 57-61.

Uceda M, Frías L. 1975. Época de recolección. Evolución del contenido graso y de la composición y la calidad del aceite. Proceeding II Seminario Oleícola Internacional, Córdoba.

Uceda M, Hermoso M. 2001. La calidad del aceite de oliva, in El cultivo del olivo. Barranco D, Fernández-Escobar R and Rallo L (Eds.) MundiPrensa, Madrid, 589-614.

Valavanidis A, Nisiotou C, Papageorgiou Y, Kremli I, Satravelas N, Zinieris N, Zygalaki H. 2004. Comparison of the radical scavenging potential of polar and lipidic fractions of olive oil and other vegetable oils under normal conditions and after thermal treatment. J. Agric. Food. Chem. 52, 2358-2365.

Velioglu YS, Mazza G, Gao L, Oomah BD. 1998. Antioxidant activity and total phenolics in selected fruits, vegetables, and grain products. J. Agric. Food. Chem. 46, 4113-4117.

Villaño D, Fernández-Pachón MS, Troncoso AM, GarcíaParrilla MC. 2006. Influence of enological practices on the antioxidant activity of wines. Food Chem. 95, 394404. 